\title{
Research on the Construction of Supply Chain Management for Undergraduate Programs at Chinese Applied Universities
}

\author{
Yanhui Li $\mathbb{D}^{1,2}{ }^{1,2}$ Yating Wei, ${ }^{2}$ Qi Yao $\mathbb{D}^{1},{ }^{1}$ and Mengsiying $\mathrm{Li}^{1}{ }^{1}$ \\ ${ }^{1}$ School of Management, Wuhan College, Wuhan 430212, China \\ ${ }^{2}$ School of Information Management, Central China Normal University, Wuhan 430079, China \\ Correspondence should be addressed to Qi Yao; 8427@whxy.edu.cn
}

Received 20 November 2020; Revised 21 December 2020; Accepted 19 January 2021; Published 30 January 2021

Academic Editor: Tingsong Wang

Copyright (c) 2021 Yanhui Li et al. This is an open access article distributed under the Creative Commons Attribution License, which permits unrestricted use, distribution, and reproduction in any medium, provided the original work is properly cited.

At present, China regards supply chain innovation and application as a new national strategy, which leads to a large demand for applied supply chain professionals. In order to provide useful references for applied universities that have already set up the supply chain management (SCM) program and promote the healthy development of China's application-oriented SCM for undergraduates, this paper discussed the necessity and feasibility of setting up the SCM program in Chinese universities. In addition, it analyzes the current situation of SCM programs from three aspects involving approval, type of universities, and issues of application-oriented undergraduate. Based on practical experience in specialty development, in this paper, specific measures were shown from three dimensions: requirements of knowledge, ability, and quality, curriculum setting, and teaching material design.

\section{Introduction}

The General Office of the State Council of China issued "the Guidance on Actively Promoting Supply Chain Innovation and Application" in 2017, which sent a clear and strong message to the whole society that China's industrial development will enter a new stage of "supply chain +." The following year, the Chinese Ministry of Education approved the establishment of supply chain management (SCM) of undergraduate programs in mainland universities, which started a great trend of talent training for undergraduates. Due to the program is new in China without reference and experience, colleges and universities are constantly exploring how to embody the application-oriented characteristics of SCM talents. Therefore, it is significant to explore the way to build application-oriented SCM undergraduate major in China.

By analyzing the progress of higher education from elitism to popularization, researchers realized that application-oriented talents who were more practical and meet social requirements would be increasingly valued in the 1990s. Robbins [1] believes that the key point of undergraduate education is to build a curriculum system with application ability as the main point while doing talent training. Greiner [2] holds the view that the training in colleges and universities cannot be separated from the orientation of employment demand; that is, in order to meet the diversified needs of market and individual enterprise, we should strengthen the communication between colleges and enterprises through active school enterprise cooperation and improve their professional quality. In terms of teaching modes, the main methods are case teaching mode, resourcebased teaching mode, task-driven teaching mode, group cooperation teaching mode, and project teaching mode. There are generous relevant empirical research results. Bilgin et al. [3] found that compared with group learning based on traditional learning methods, undergraduate students that based on project-based learning have more self-efficacy beliefs in learning through comparative analysis of experiments. Rogers and Braziotis [4] believed that some commonly used methods (such as case studies, classroom discussions, and individual and group work) do not seem to be the most important methods in the future, while commercial games/simulations and competitions seem to be the preferred teaching methods. Similar to Helen's research, Chuang [5] helps students think logically and systematically 
through scenarios of uncertainty and complexity, so as to cope with the challenges of responsive supply chains. Nguyen [6] showed that although the traditional teaching methods (such as the inductive method, active learning method, the participatory teaching method, and inquiry teaching strategy) are effective, nowadays, most of the teaching makes a mixture of traditional and nontraditional methods.

The study of the higher education system focuses more on how to train students to meet social needs from the perspective of curriculum setting. Elliott and Paton [7] believe that as the world continues to follow the path of specialization, the flexibility of students' educational should to be improved constantly. The flexible course selection system will enhance the adaptability and responsiveness of undergraduate education to meet the changing social demand. SCM is a discipline that requires students to make decisions and invent new solutions, which forces students to understand the tactical and strategic decisions of enterprises [8]. In recent years, with more breakthrough technologies enter the market, enterprises should change the job requirements. And it increases the academic pressure of undergraduates in SCM [9]. Sodhi et al. [10] studied some of the top 50 business school postgraduate courses in the US, including 37 SCM optional course and 36 core courses in operation management. Their analysis shows that there is a gap between industry demand and SCM courses, while Western Michigan University (WMU) offers the integrated supply management (ISM) program to focus on creating value for students while meeting the needs of the professionals through its experiential learning program. Because students learn technology and soft skills in an interactive environment, SCM education integrates more experiential learning courses [11]. Curkovic and Fernandez [12] proved that the ISM program at WMU successfully narrowed the gap between graduates' abilities and employers' expectations through continuous collaboration with the industry.

\section{The Necessity and Feasibility of Establishing the SCM Program in China}

2.1. Meeting the Needs of Economic Development. As the second largest economy in the world, China has actively integrated into the development trend of the global economy. "One belt, one road," and "Internet+" have effectively promoted the free operation of market and economic factors, and it promoted the formation of global industrial chains, global value chains, and global supply chains. Blanchard, a senior researcher at the Peterson Institute of International Economics (PIIE) said that China has been deeply involved in the global supply chain $[13,14]$. A report by HIS Markit, a British market research organization, shows that while China continues to be a purchasing destination, it is no longer "a target country for low-cost outsourcing business" but "a center of the global supply chain that it has leapt to" [15].

Most of the traditional management and operation modes of Chinese enterprises are self-contained and relatively closed, and they pay little attention to open SCM. In this case, manufacturers, suppliers, and distributors lack long-term strategic partnership. They lack a value chain and mutual trust, so it is difficult to get the profits effectively and meet the requirements of customers in the aspects of cost, quality, delivery time, and experience. It is also difficult to form a sensitive pattern of business flow, logistics, capital flow, and information flow. It is necessary to speed up the promotion of enterprises to take market demand as the guidance and to be market demand oriented, which will creative a win-win situation with upstream and downstream enterprises and final consumers. It can also effectively connect business flow, logistics, information flow, capital flow, and business flow to achieve seamless integration between enterprises, and improve the response speed of the entire supply chain, form the optimization of the logistics of the entire supply chain. It is one of the main trends of modern economic development to improve the internal supply chain architecture of enterprises, improve the operation efficiency of the overall supply chain, and reduce the operation cost of the supply chain by making use of efficient external supply chain service platform and relying on the services provided by professional SCM companies.

2.2. Huge Market Demand. With the continuous influence of economic globalization and Internet, the flow of goods, information, and capital in the supply chain will all be connected to the Internet. And with the help of the latest information technologies such as big data and cloud computing, traditional industries are seamlessly integrated with the new economy, ushering in a new cycle of development. According to the China Logistics Development Report [16], the compound growth rate of China's logistics and supply chain in the next five years will reach $15 \%$, and the market value will reach 3.2 trillion US dollars in 2020 . $70 \%$ of the supply chain outsourcing providers have experienced annual business growth of more than $20 \%$ over the past three years. In addition, according to the forecast of the Qianzhan Industry Research Institute [17], the market size of China's SCM services will reach 3.1 trillion US dollars in 2020, as shown in Figure 1. And the compound growth rate of the market value of China's logistics and supply chain services in the next five years will remain at about $15 \%$.

The rapid development of SCM service market has put forward urgent demand for SCM talents. According to the latest statistics of China Employment Training Technical Guidance Center (CETTIC), there are more than 5 million logistics and SCM employees in China, and only $50 \%$ of the graduates majored in business administration, logistics management, and SCM (2019). Among them, the interdisciplinary supply chain talents who can cope with the challenges of globalization have Internet thinking and are familiar with the knowledge and operation of various subdivisions of the supply chain are rare and scarce that are about 50,000 people, accounting for only $1 \%$. So, cross-border talents who can adapt to the complex environment of global supply chain (familiar with procurement, logistics, trade, information technology, e-commerce, law, and other fields at the same time) will become the focus of competition for all enterprises. 


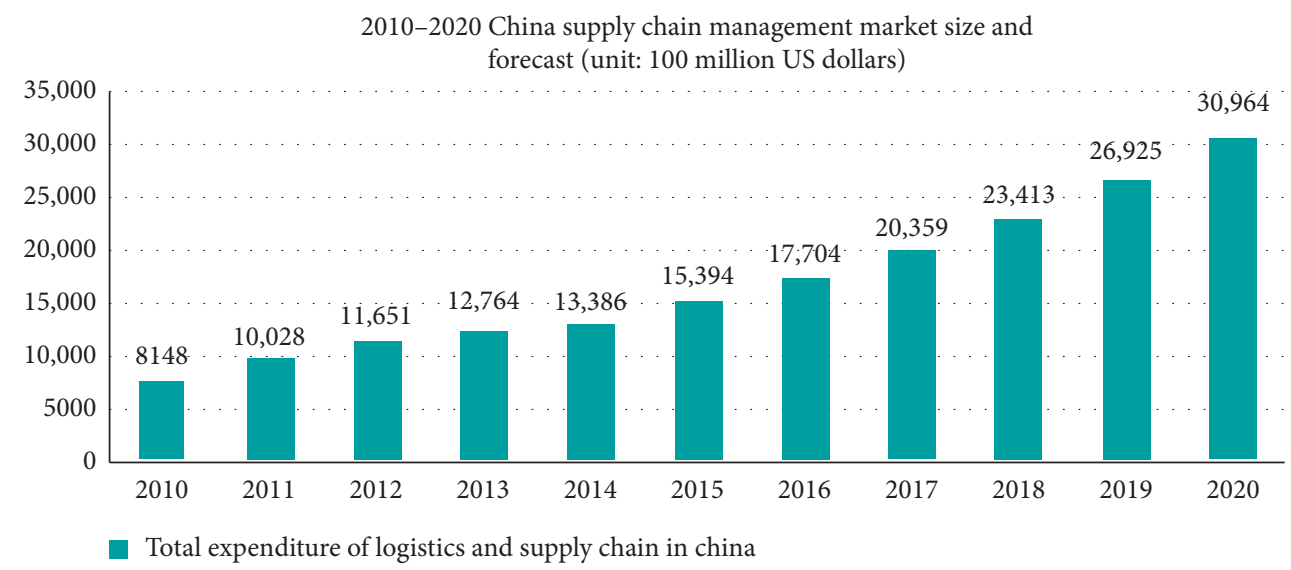

FIgURE 1: Market size and forecast of SCM services in China from 2010 to 2020. Source: Qianzhan database.

2.3. International Experience for Reference. According to our survey of relevant universities in the US, Hong Kong, and mainland China, the SCM program is generally located in the school of management or business school, while some universities offer the major under Industry Engineering. There are three main directions for this program: First, research on SCM methods; second, supply chain model analysis and research; and the third one is a branch of the MBA. The graduates are mainly engaged in logistics planning, global procurement, supply management analysis, and other professions. Their work fields involve manufacturing, service, health, retail, and other industries.

2.3.1. SCM Programs in American Universities. As companies operate across borders, manufacturing, retail, and technology companies, as well as the consulting firms, are in desperate need of talent in SCM. World-renowned universities, including Michigan State University (MSU) and the Massachusetts Institute of Technology (MIT), have set up the SCM program. From 2011 to 2014, eight US universities have set up undergraduate program, MBA, and even all degree courses on purchasing, inventory management, and international supply chain strategy (see Table 1).

In the United States, SCM graduates are in great demand, and their income level is considerable. At Arizona State University (ASU), the average starting salary for a supply chain undergraduate in 2012 was $\$ 56,410$, while that for a business undergraduate was $\$ 50,098$. As for the MBA level, the starting salary for students who are in charge of operations or supply chain work is $\$ 97,481$, while the average MBA salary is $\$ 92,556$.

2.3.2. SCM Programs in Hong Kong. Hong Kong has always been a global logistics and trade hub, maintaining its status as the world's busiest container port and international air cargo center for many years. Due to the vigorous promotion of the Hong Kong government and the influence of a number of cooperation policies between China and Hong Kong, the development of the trade and logistics industry in Hong Kong is more vigorous, and there is a great demand for SCM professionals in the market.
The Hong Kong Polytechnic University (PolyU) offers the Bachelor of Business Administration (Honours) in Global SCM for the school of business administration. The course focuses on operation management, information technology, cross-departmental management, global trade, and transportation processes and provides students with comprehensive and professional industry knowledge, so that they can prepare for the logistics industry. In addition to the diversity of subjects, the most important feature of the course is interaction and activity teaching. Through different case analysis, role playing, and simulation exercises, students can be exposed to more practical cases and train their thinking. The course will arrange students to visit enterprises and organizations in the industry and invite experienced staff to share their experiences, so as to broaden students' international vision. Due to the wide coverage of the courses, graduates can gain in-depth understanding of transportation logistics, supply chain logistics, and enterprise management. Therefore, there are a lot of options for employment, and they can be engaged in SCM in procurement, shipping, transportation, retail and wholesale, and other industries.

The School of Business at Hang Seng University of Hong Kong (HSUHK) launched the Bachelor of Business Administration (Honours) in SCM (BBA-SCM) in 2010. And the course was invited by the Education Bureau to join the "designated professional/sector course funding scheme" of the Education Bureau of the Hong Kong Special Administrative Region in 2015. The following year, it was awarded the subject scope certification by the Hong Kong Council of Academic and Vocational Qualifications. At present, it is recognized as one of the largest supply chain and logistics management courses in Greater China.

BBA-SCM is a four-year program in the school of decision science, with two semesters (15 weeks) per year. Each project module of BBA-SCM contains three credits, and each credit has at least 15 face-to-face class hours. In the four-year system, students are required to complete at least 43 modules with a total of 129 credits. The BBA-SCM project has designed two professional directions. The first direction is designed for those students who want to continue to study in the supply chain and logistics related fields, while the second direction is designed for those students who want to 
TABle 1: New SCM program in some American universities.

\begin{tabular}{|c|c|c|c|}
\hline Universities & Location & Course & $\begin{array}{l}\text { Beginning } \\
\text { year }\end{array}$ \\
\hline Bauer School of Business, University of Houston & Houston & SCM, MBA & 2011 \\
\hline Rutgers Business School & New Jersey & Bachelor of SCM & 2011 \\
\hline Business School, Bryant University & $\begin{array}{l}\text { Smithfield, Rhode } \\
\text { Island }\end{array}$ & $\begin{array}{c}\text { Bachelor degree and MBA in } \\
\text { international SCM }\end{array}$ & 2012 \\
\hline $\begin{array}{l}\text { School of Business and Public Administration, Governor } \\
\text { State University }\end{array}$ & $\begin{array}{l}\text { University Park, } \\
\text { Illinois }\end{array}$ & SCM MBA online course & 2013 \\
\hline Business School, Portland State University & Portland, Oregon & Master of Science in international SCM & 2013 \\
\hline Nylie School of Business, Texas Christian University & Fort Worth, Texas & MSc SCM & 2013 \\
\hline $\begin{array}{l}\text { Marshall School of Business, University of Southern } \\
\text { California }\end{array}$ & Los Angeles & MSc international SCM online course & 2013 \\
\hline W. P. Carey School of Business, Arizona State University & Tempe, Arizona & $\begin{array}{l}\text { Bachelor of Science in SCM } \\
\text { Bachelor of SCM and operations }\end{array}$ & 2014 \\
\hline
\end{tabular}

carry out professional training in related practical work. Both of the directions provide students with a foundation to seek development opportunities in the field of business and SCM. The BBA-SCM project works closely with industrial institutions and enterprises, and it provides students with opportunities for vocational training and professional qualification examinations.

\section{The Construction of SCM Programs in China}

3.1. SCM Programs Approved to Be Constructed. In 2017, Wuhan College (WHXY), an application-oriented private university in mainland China, applied to the Ministry of Education of China to establish the undergraduate program of "global supply chain and the informationization." After the evaluation of the Teaching Guidance Committee in Higher Educational Institutions of Chinese universities, the Ministry of Education approved the request, which made WHXY the only one institution qualified to open this major. Since then, as a formal undergraduate major, SCM has been listed in the subclass of "logistics management and engineering" in the Catalogue of Undergraduate Majors in Higher Education (CUMHE) and has been given professional code, 120604T. After finishing their four-year studies, the students receive the management degree. From 2018, WHXY began to recruit undergraduate students majoring in SCM, marking the beginning of undergraduate education in SCM in mainland China.

In China, it will be relatively easy for Chinese universities to set up a program when it is included in the CUMHE and has a unique code. This is because the follow-up application process adopts the filing system, and the universities that meet the requirements apply to the Ministry of Education and can be approved after the reviews and records. Many Chinese universities are actively applying for an SCM undergraduate program, especially those that already offer logistics management and engineering. Following to Wuhan College initiative, in 2019 other seven universities, as well as, in 2020, 17 universities, also have been approved by the Ministry of Education to offer the undergraduate SCM program. Therefore, there are in total 25 universities in China that offer this program, as shown in Table 2.
3.2. Analysis of School Types. Universities are mainly classified from two perspectives inside the Chinese classification system: (1) from the perspective of the school running system, it can be divided into three categories: public university, private university, and independent college; (2) from the perspective of research strength, it can be divided into research-oriented universities and application-oriented universities. The 25 universities mentioned in this paper cover five types of two dimensions. Next, it will analyze from these two dimensions.

In terms of the school running system, 4 of the 25 universities are private universities. They are WHXY, XJTLU, BCU, and HXXY, accounting for $16 \%$ of the total, while CUC, GCU, and CQYTI are independent colleges, accounting for $12 \%$ of all. The rest are public universities, accounting for $72 \%$ of all. From this point of view, public universities still account for the main share.

As for research strength, 8 universities are researchoriented universities, and they are CUFE, SMU, SDU, SWUFE, DMU, BTBU, AHNU, and HAUT, accounting for $32 \%$ of the 25 universities. And all of them are all public universities. The remaining 17 universities, whether public, private, or independent, are all applied universities, accounting for $68 \%$. It can be seen that the SCM program in China is mainly application-oriented university and covers three different school running systems. Therefore, it is of great significance to focus on application-oriented universities.

3.3. Some Issues at Application-Oriented Universities. At present, there are two dilemmas in developing competencies of SCM students. One dilemma is about training SCM professionals in China, because it mainly relies on postgraduate programs of Management Science and Engineering, as well as, Logistics Engineering, which mainly focused on the mastery and application of students' basic theoretical knowledge and the cultivation of scientific research as well as innovation ability. In this case, students' ability to solve practical problems and their hands-on ability is relatively insufficient, so it is difficult to meet the needs of social application-oriented talents. 
TABLE 2: List of universities that are specialized in SCM.

\begin{tabular}{|c|c|}
\hline School name & Year \\
\hline Wuhan College (WHXY) & 2017 \\
\hline Central University of Finance and Economics (CUFE) & 2018 \\
\hline Beijing Wuzi University (BWU) & 2018 \\
\hline Baoding University (BDU) & 2018 \\
\hline Yingkou Institute of Technology (YKU) & 2018 \\
\hline Shanghai Maritime University (SMU) & 2018 \\
\hline Xi'an Jiaotong-Liverpool University (XJTLU) & 2018 \\
\hline Hefei University (HFUU) & 2018 \\
\hline Shandong University (SDU) & 2019 \\
\hline Southwestern University of Finance and Economics (SWUFE) & 2019 \\
\hline Dalian Maritime University (DMU) & 2019 \\
\hline Beijing Technology and Business University (BTBU) & 2019 \\
\hline Beijing City University (BCU) & 2019 \\
\hline Zhejiang Wanli University (ZWU) & 2019 \\
\hline Anhui Normal University (AHNU) & 2019 \\
\hline Bengbu University (BBC) & 2019 \\
\hline Xiamen Huaxia University (HXXY) & 2019 \\
\hline Chengyi College of Jimei University (CUC) & 2019 \\
\hline Henan University of Technology (HAUT) & 2019 \\
\hline Hunan Business University (HUTB) & 2019 \\
\hline Guangzhou College of South China University of Technology (GCU) & 2019 \\
\hline Chongqing University of Science and Technology (CQUST) & 2019 \\
\hline College of Mobile Telecommunications, Chongqing University of Posts and Telecommunications (CQYTI) & 2019 \\
\hline Chongqing University of Education (CQUE) & 2019 \\
\hline Chengdu University of Information Technology (CUIT) & 2019 \\
\hline
\end{tabular}

The second dilemma is that some universities are over emphasis research and neglect practice education. There is a trend that colleges and universities generally attach great importance to the vocational skills training based on logistics management and technology, overemphasizing the cultivation of students' operation skills, while ignoring the mastery of the necessary basic theoretical knowledge, which is similar to the mode of secondary and higher vocational education. As a result, it does not help students' career development after their graduation.

\section{Measures}

The directions of the above two modes of personnel training are opposite, and it cannot be consistent with the training objectives of application-oriented universities. The cultivation of talents in application-oriented universities should be different from both research universities and vocational education. The graduates should not only master the basic theories, but also the professional skills in the field of SCM, and have strong practical ability. Based on the idea, we have taken the following measures to achieve this goal.

\subsection{Ability, Knowledge, and Diathesis of Students}

4.1.1. Ability of Students. Through the study of various courses, the graduation of the SCM program should achieve the following expected abilities:

(1) The ability to make correct value judgment and behavior choice from the perspective of Marxism.
The ability of thinking, expressing, and writing; the ability of innovation and independent work (A1)

(2) Effective communication, teamwork skills, and basic social skills (A2)

(3) IT ability to quickly access and act on digital data; engage in lifelong learning to meet future career challenges (A3)

(4) Understanding big data processing and analytics; ability to analyze and optimize the supply chain with tools, technologies, and frameworks (A4)

(5) To meet the needs of customers and improve supply chain efficiency, achieve cross-functional and crossorganizational boundary management (A5)

(6) With system thinking and innovative spirit, ability to think and act in different ways to solve problems in an ever-changing environment (A6)

4.1.2. Knowledge of Students. Through the study of various courses in SCM, the graduates should have the following knowledge:

(1) Mastering the true spirit of Marxism and grasping the combining of Marxism and China's reality (K1)

(2) Understand the relevant technical standards, advanced technology, and development trend of SCM (K2)

(3) Have basic knowledge of natural sciences such as humanities and social sciences, computer science, and advanced mathematics (K3) 
(4) Master the basic theory and knowledge of economics, management, financial management, accounting, production and operation management, and marketing (K4)

(5) Know well the theory and application method of supply chain planning and design, such as business data analysis, supply chain analysis method, supply chain planning, and simulation (K5)

(6) Master the core theories and application methods of logistics management, procurement and supply management, supply chain strategic management, supply chain finance, supply chain information system, supply chain financial analysis, and performance management (K6)

(7) Familiar with the practice process of proprietary trading and pop operation in Jingdong supply chain management (K7)

4.1.3. Diathesis of Students. The program focuses on cultivating applied talents and their value-added in the future with the concept of "Whole Person Development," and it has four core qualities: ideal ambition, governance capacity, excellent morals and academic skills, and overall situation. After studying professional courses, graduates should have the following 12 diathesis: keep the world in view (D1); social responsibility (D2); lifelong learning (D3); innovation and entrepreneurship ability (D4); leadership (D5); critical thinking (D6); individual self-restraint (D7); noble virtues (D8); professionalism (D9); resolve difficulties (D10); selfesteem and confidence (D11); geniality (D12). The details are as follows:

(1) Have good political quality, ideological and moral quality, cultural quality, physical quality, psychological quality, and the spirit of cooperation (D2, D7, and D12)

(2) Have the ability and attitude of self-reliance and selfimprovement, have ideals and aspirations, and have a sense of responsibility (D5, D9, and D11)

(3) Have a sense of social responsibility and critical spirit (D2 and D6)

(4) Have a rigorous and positive attitude at work and attach importance to the awareness of innovation and entrepreneurship (D4 and D5)

(5) Have noble morality, stay in good mental and physical health, and pay attention to scientific spirit with humanistic touch (D8 and D10)

(6) Have a sense of responsibility and develop self-directed learning and lifelong learning (D1 and D3)

4.2. Curriculum System Setting. Table 3 shows the corresponding relationship between ability, knowledge, diathesis, and curriculum [18]. It puts requirement of ability, knowledge, and accomplishment into the specific teaching course, so as to achieve the expected training objectives in these aspects and form a complete curriculum system.
Table 4 shows the course credit distribution, and Table 5 shows the practice credit distribution.

As shown in the table, practical credits account for $31.51 \%$. Through open experimental teaching, students can participate in a series of activities such as market analysis, strategy formulation, production organization, overall marketing, and financial settlement, so as to realize the supply chain integrity, understand the interoperability of logistics, capital flow, and information flow in the supply chain, and make them become skilled talents to meet social needs.

4.3. Creating Effective Teaching Materials. The core knowledge system of the SCM program includes supply chain strategic management, supply chain planning and design, and supply chain operation management. The authoritative materials in this field are mainly in Europe and America. "Purchasing and Supply Chain Management" by Lysons and Farrington [19] is the textbook of the Chartered Institute of Procurement and Supply (CIPS) in the UK which comprehensively explains various supply chain-related concepts. Martin [20] introduces the main professional ideas and the development direction of supply chain in "logistics and supply chain management." The famous teaching material of SCM subdivision field is Purchasing and Supply Chain Management [21]. The author integrates many elements into one definition, which is highly professional. And "The Handbook of Logistics and Distribution Management: Understanding the Supply Chain" by Alan is the representative CIPS textbook in warehousing logistics. After actively participating in the discussion of the state education commission and organizing many domestic experts and scholars' symposiums in the field of SCM, this paper discussed and determined the following 10 textbooks, such as "Basis of Supply Chain Management," "Supply Chain Strategic Management," "Supply Chain Risk Management," "Supply Chain Finance," "Supply Chain Planning and Design," "Purchasing and Supply Management," "Jingdong Supply Chain Management Experimental Teaching Guide," "Supply Chain Operation Management," "Supply Chain Case Analysis," and "Supplier Performance and Contract Management."

In order to meet the social needs in the field of supply chain, this series of teaching materials draw lessons from excellent teaching materials' writing ideas and methods in the world and focus on the professional knowledge as well as skills. In addition, the future industry development trend and cutting-edge materials will be shown to students in the form of reading materials. The theoretical knowledge of this teaching materials attaches great importance to the systematicness and foundation, while the skill modules focus on the practicability and effectiveness, especially the application of methods, techniques, charts, and tools. It is organically integrated with a large number of the latest cases for systematic analysis, or to give a large number of calculation examples that are combined with practical application scenarios. In brief, the aim is to emphasize the inspiration and exercise of students' thinking and improve the comprehensive ability of students to solve practical problems. 
TABLE 3: Corresponding relation of knowledge, ability, diathesis, and curriculum.

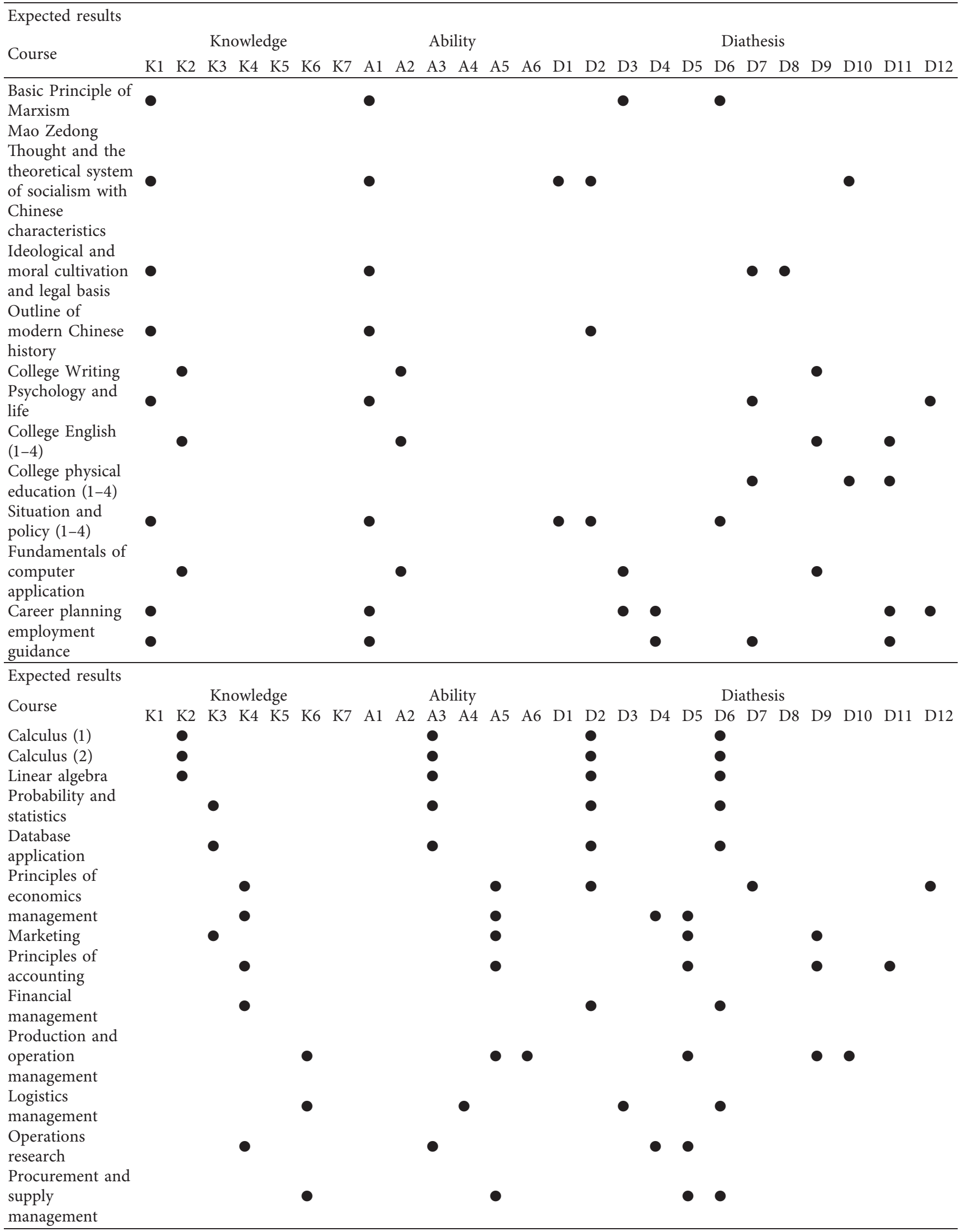


TABle 3: Continued.

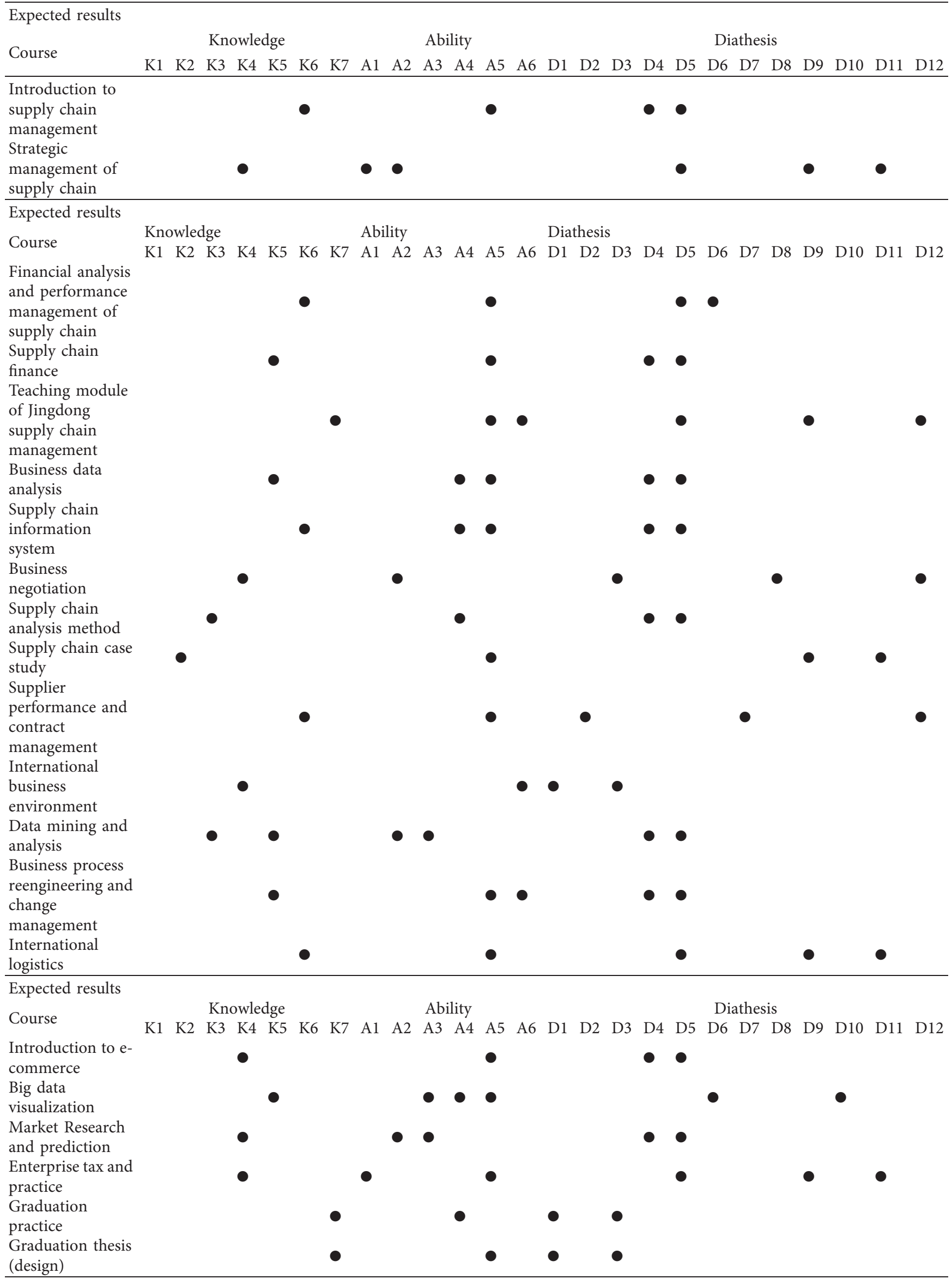


TABLE 4: Credit distribution.

\begin{tabular}{|c|c|c|c|c|c|}
\hline Course category & & & Class hour & $\begin{array}{l}\text { Prop } \\
\text { total }\end{array}$ & $\begin{array}{l}\text { n of } \\
\text { hours }\end{array}$ \\
\hline \multirow{8}{*}{ Class instructions } & \multirow{4}{*}{ Compulsory course } & General education curriculum & 44 & 26.67 & \multirow{4}{*}{76.98} \\
\hline & & Basic courses & 33 & 20.00 & \\
\hline & & Professional courses & 39 & 23.64 & \\
\hline & & Modular practice course & 11 & 6.67 & \\
\hline & \multirow{4}{*}{ Optional course } & General education curriculum & 10 & 6.06 & \multirow{4}{*}{23.02} \\
\hline & & Professional courses & 14 & 8.48 & \\
\hline & & Modular practice course & 4 & 2.42 & \\
\hline & & Whole person development education & 10 & 6.06 & \\
\hline Total & & & 165 & & 100 \\
\hline
\end{tabular}

TABle 5: Practice credit distribution.

\begin{tabular}{lcc}
\hline Category & Credits & Proportion of total credits (\%) \\
\hline Independent setting experiment & 3 & 1.2 \\
Modular practice course & 12 & 727 \\
Whole person development education & 10 & 606 \\
Practice and experiment in class & 27 & 1636 \\
Total & $\mathbf{5 2}$ & $\mathbf{3 1 5 1}$ \\
\hline
\end{tabular}

\subsection{Teaching Method}

4.4.1. Comprehensive Application of Different Teaching Methods. Teachers should focus on using different teaching methods, widening the breadth of knowledge and classroom space, to improve students' class participation. The teaching methods that can be used are case studies, game-based learning, watching videos, and enterprise training. The case study requires teachers to provide related cases for students and lead them to analyze and solve the practical problems of the enterprise by using the knowledge they have learned; game-based learning is a teaching method that allows teachers to design a series of attractive scenarios for the students as a form of learning; in the enterprise training method, teachers always organize students to study or research in enterprises, so that students can deepen their understanding of various theoretical knowledge. In brief, during the teaching, the teacher mobilizes and stimulates the students' learning interest, enthusiasm, and initiative fully by adopting variety of teaching methods.

4.4.2. Construction of Training Base. Teachers should realize the importance of practice teaching in the course of supply chain management. An important evaluation standard of high-quality talents is practical operation ability; in other words, students need to quickly adapt to the needs of work and apply theoretical knowledge to practical activities, which is also the quality of applied talents. In order to enable students to adapt to the requirements of the job as soon as possible, universities should set up relevant training bases for supply chain management and provide a good environment for the growth of applied talents. For example, schools can sign student training agreements with supermarkets, high-quality logistics enterprises, and manufacturing enterprises. Through effective communication between schools and enterprises, students can get more practical learning.

4.4.3. Reform of Student Assessment Method. Different assessment methods of teaching effect need to be adopted. Universities should reform the traditional way of assessing students' performance in the form of written examination, and teachers should pay more attention to the assessment of professional ability. For example, students can be assessed through the group work, case lectures, class discussions, classroom performance, and homework. Teachers can also combine theory examination with practical training skill assessment according to the content of training report. The students trained in this way will not only master the theoretical knowledge but also pay more attention to the cultivation of practical ability.

\section{Conclusion}

Supply chain innovation and application has reached the national strategic level for China. In this case, Chinese government departments, enterprises, and industries attach great importance to SCM, which constitutes a huge demand for SCM application-oriented talents. Therefore, Chinese universities should comply with the trend to build the SCM program and especially pay attention to the characteristics of application-oriented talents. At present, many applicationoriented universities have set up the SCM undergraduate program. However, this is a brand-new major, and there are still many issues to be explored due to the lack of replicable experience. Through the research, this paper attempts to put forward some reasonable suggestions. 
This paper introduces the practical background of the SCM undergraduate program in Chinese universities, analyzes the necessity and feasibility of setting up this program, and discusses the present SCM programs in Chinese universities. Based on practical experience, it gives a series of corresponding construction measures, which is of great significance for the development of SCM program in China's application-oriented universities.

Due to the limited time of setting up this program in China and our insufficient experience, there are some limitations in this study. For example, whether the teaching materials can meet the needs of students and whether graduates can meet the social requirements need to be verified. In the future, the research can be carried out from the following aspects: (1) research on teaching methods for application-oriented SCM undergraduate talents training; (2) research on teaching applicability of application-oriented SCM teaching materials; (3) empirical research on the satisfaction of applied SCM talents to social requirements.

\section{Data Availability}

The data used to support the findings of the study are available from the corresponding author upon request.

\section{Conflicts of Interest}

The authors declare that they have no conflicts of interest.

\section{Acknowledgments}

This study was supported by the Research and Innovation Platform Construction Plan of Wuhan College (grant no. KYP201901), National Natural Science Foundation of China (grant no. 71471073), and Fundamental Research Funds for the Central Universities (grant no. CCNU19TS078).

\section{References}

[1] S. P. Robbins, Organiazation Behavior, Prentice-Hall International, Inc, London, UK, 7 edition, 1997.

[2] A. Greiner, "On the dynamics of an endogenous with Learning by doing," Economic Theory, vol. 21, no. 1, pp. 201-214, 2003.

[3] I. Bilgin, Y. Karakuyu, and Y. Ay, "The effects of project based learning on undergraduate students' achievement and selfefficacy beliefs towards science teaching," Eurasia Journal of Mathematics, Science \& Technology Education, vol. 11, no. 3, pp. 469-477, 2015.

[4] H. Rogers and C. Braziotis, "Current issues in teaching logistics management," in Proceedings of the 4th International Conference LDIC, pp. 553-563, Bremen, Germany, 2014.

[5] M.-L. Chuang, "A web-based simulation game for teaching supply chain management," Management Teaching Review, vol. 5 , no. 3, p. $265,2019$.

[6] K. Nguyen, R. DeMonbrun, M. Borrego et al., "The variation of nontraditional teaching methods across 17 undergraduate engineering classrooms," in Proceedings of the 2017 ASEE Annual Conference \& Exposition, Columbus, OH, USA, June 2017.

[7] R. W. Elliott and V. O. Paton, "U.S. higher education reform: Origins and impact of student curricular choice,"
International Journal of Educational Development, vol. 61, no. 61, pp. 1-4, 2018.

[8] K. Cottrill, Are You Prepared for the Supply Chain Talent Crisis?, MIT Center for Transportation Logistics, Cambridge, MA, USA, 2010.

[9] MHI, The 2016 MHI Annual Industry Report, MHI Report, 2017, https://www.mhi.org/publications/report.

[10] M. S. Sodhi, B.-G. Son, and C. S. Tang, "ASP, the art and science of practice: what employers demand from applicants for MBA-level supply chain jobs and the coverage of supply chain topics in MBA courses," Interfaces, vol. 38, no. 6, pp. 469-484, 2008.

[11] E. Stuba, S. Curkovic, and B. Wagner, "The benefits of simulated coursework in Western Michigan University's undergraduate supply chain program," Creative Education, vol. 08, no. 12, pp. 1821-1832, 2017.

[12] S. Curkovic and N. Fernandez, "Closing the gap in undergraduate supply chain education through live experiential learning," American Journal of Industrial and Business Management, vol. 6, no. 6, pp. 697-708, 2016.

[13] People's Daily: China becomes center of global supply chain [DB/OL], 2017, http://english.www.gov.cn/news/top_news/ 2017/02/10/content_281475564088064.htm.

[14] O. Blanchard, Light of the Elections: Recession, Expansion, and Inequality, Peterson Institute for International Economics, Washington, DC, USA, 2016.

[15] IHS Markit, "Survey on New Trends of Global Procurement," IHS Markit, London, UK, 2017.

[16] CFLP and CLA, China Logistics Development Report, China Fortune Publishing House, Beijing, China, 2016.

[17] Qianzhan Industry Research Institute, Report on China Supply Chain Management Service Industry, FORWARD Business Information Co., Ltd., New Taipei City, Taiwan, 2016, in Chinese.

[18] WHXY Talent, Training Program of Supply Chain Management, Wuhan College, Wuhan, China, 2019, in Chinese.

[19] K. Lysons and B. Farrington, Purchasing and Supply Chain Management, Trans-Atlantic Publications, Philadelphia, PA, USA, 2004.

[20] C. Martin, Logistics \& Supply Chain Management, Pearson Education, Edinburgh, Scotland, 3 edition, 1998.

[21] J. V. W. Arjan, Purchasing and Supply Chain Management, Cengage Learning, London, UK, 7 edition, 2009. 